$\mathbb{T}$ periodica polytechnica

Transportation Engineering

41/2 (2013) 111 115

doi: $10.3311 /$ PPtr.7110

http://periodicapolytechnica.org/tr

Creative Commons Attribution (i)

RESEARCH ARTICLE

\section{Structure and mechanical properties of fine-grained steels}

\author{
Robert Ulewicz / Magdalena Mazur / Otakar Bokůvka
}

Received 2013-09-04

\begin{abstract}
In this article was determined the influence of alloying elements on changes in the structure and properties of the selected grade of fine grained steel. The main objective of research that was carried out, was to provide independent results to the company which uses Hardox 400 and 450 steel in the construction of semi-trailers. To this end, researches of selected mechanical properties and fatigue tests were carried out. For this purpose, samples were prepared for fatigue research on the device Rotoflex for Hardox 400 and 450 and as reference samples for S355J2 steel, which is also used in the construction of semitrailers by Wielton S.A.
\end{abstract}

\section{Keywords}

Fatigue tests · Whöler's curve · Fine-grained steel

\section{Acknowledgement}

The project presented in this article is supported by "DoktoRIS - Scholarship program for innovative Silesia" co-financed by the European Union under the European Social Fund.

\section{Robert Ulewicz}

Institute of Production Engineering, Czestochowa University of Technology, Poland

e-mail: ulewicz@zim.pcz.pl

\section{Magdalena Mazur}

Institute of Production Engineering, Czestochowa University of Technology, Poland

e-mail: mazur.m@zim.pcz.pl

\section{Otakar Bokůvka}

Department of Materials Engineering, University of Žilina,

Univerzitná 1, 01026 Žilina, Slovakia

e-mail: otakar.bokuvka@fstroj.uniza.sk

\section{Introduction}

Manufacturers, including in the ones of automotive industry, are mainly interested in optimizing operating costs and increasing production. So they pay attention to obtain the highest level of durability of transport objects that are produced, by the search for new construction solutions of products and the use of appropriate materials (materials with appropriate characteristics). The research, that is conducted in collaboration with WIELON S.A. company is aimed at understanding the fatigue properties of selected types of steel (Hardox 400, Hardox 450, Domex 700MC, Docol). To confirm the accuracy of carried out researches, obtained results will be compared with the results of conventional structural steel S355J2. Later during the research, obtained steel characteristics will be the basis for determining the next uses for the steel in the construction of semi-trailers designed in the WIELTON S.A. (Ulewicz et al. [13]).

$\mathrm{S} 355 \mathrm{~J} 2$ steel is mainly used to produce general-purpose welded elements. This material is used for parts of: machinery in the building industry, construction components, carriages, large diameter pipes, etc. S355J2 steel has good welding properties, which contributes to its wide range of technical uses. Depending on the needs and the product range, it is present in raw or normalized form. In specific cases, the quenching and tempering are applied (Borkowski et al. [3]). According to the manufacturer information, Hardox steels are defined as "high-quality abrasion-resistant steels". They are characterized by high resistance to abrasive wear, the possibility of specialized machining tools, good weldability, excellent mechanical properties and resistance to impact loads. Hardox steels are produced in six types. Among the six types of materials most widely used in the construction of tippers is Hardox 400 and 450. Other types, such as Hardox 500, are used as working elements of buckets in TUR-type loader. In 2005, was proposed change in the material used for construction of the sides, bottom and arch trucks cars used to transport ore (ZANAM-LEGMET Polkowice) of Hardox 400 on Hardox 450 (Dudiński et al. [5]). The change from Hardox 400 sheet to Hardox 450 one allows you to create lighter construction of a trailer or to extend the period of its operation and sometimes both of these elements occur together. 
After crossing the sheet 450 Hardox is possible to use in the design of thinner sheet metal, provided that this does not occur by a significant decrease in fatigue strength, stability in the whole structure. The hardness of steel Hardox 450 is greater than about 50 degrees Brinell. The feature of this steel type allows you to extend the life of structural components up to $80 \%$ (Dima et al. [4], Krynke et al. [6]).

\section{Heat treatment - the influence of alloy addition}

The characteristic features of Hardox steel are: fineness in normalized state (after heat-treatment resulting in finedispersion after-martensitic structures), very high strength properties and specially emphasized by the manufacturer good resistance to abrasive wear.

Discussed characteristics of steel are achieved by precisely balanced chemical composition and low content of harmful impurities of phosphorus and sulfur. Table 1 shows chemical compositions and Table 2 shows selected mechanical properties of Hardox 400 and Hardox 450 steel.

Within the same brand Hardox steels have diversified carbon and alloy additions contents $(\mathrm{Cr}, \mathrm{Ni}, \mathrm{Mo})$. This diversification is dependent on sheet thickness and cooling rate. In this way, with constant content of boron $(\max 0.004 \% \mathrm{~B})$ is regulated hardenability of these materials in order to achieve homogeneous sheet structure. In addition to carbon content Hardox structure is determined by alloying additions: nickel, manganese, chrome, molybdenum and aforementioned boron. Their influence on structures and properties of Hardox steel is varied and their amounts are selected in such way that they strictly regulate their hardness (Palček et al. [9]).

The study results showed that the yield strength in the transverse direction and the longitudinal direction of rolling sheet exceeds the $1000 \mathrm{MPa}$. Figure 1 shows the results of tensile tests of Hardox 400 and 450 in the longitudinal and transverse direction.

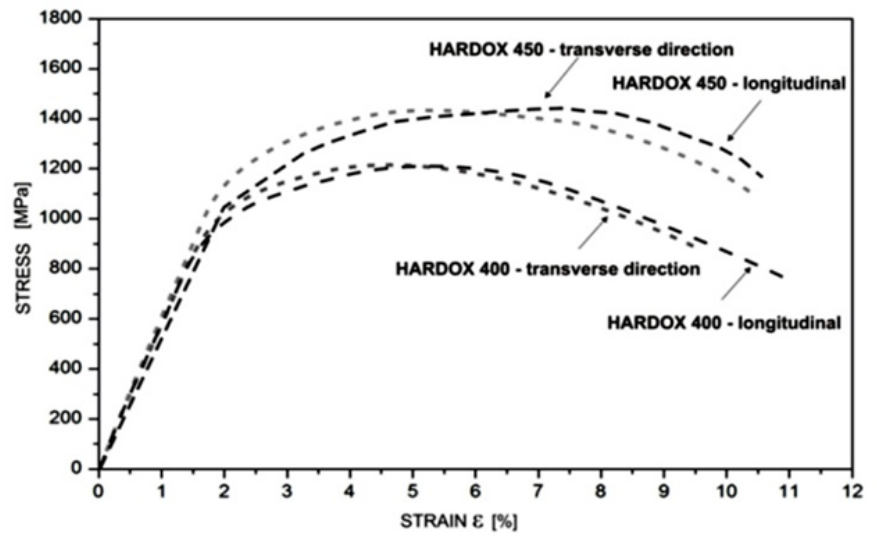

Fig. 1. Tensile test characteristic for Hardox 400 and 450 samples

The increase of Hardox steel hardenability is affected by manganese among other things, but only in amounts not exceeding $1.6 \%$. Manganese increases hardenability and can cause decreease in the size of ferrite grains during hot rolling. The increase of Hardox steel hardenability is also caused by
Tab. 2. Mechanical properties Hardox 400 and Hardox 450 steel

\begin{tabular}{cccccc}
\hline \multirow{2}{*}{ Steel } & Hardness & $\mathrm{R}_{\mathrm{p} 0.2}$ & $\mathrm{R}_{\mathrm{m}}$ & $\mathrm{A}_{5}$ & $\mathrm{KV}_{-40}$ \\
\cline { 2 - 6 } & $(\mathrm{HB})$ & $(\mathrm{MPa})$ & $(\mathrm{MPa})$ & $(\%)$ & $(\mathrm{J})$ \\
\hline Hardox 400 & $370 \div 430$ & 1000 & 1250 & 10 & 45 \\
Hardox 450 & $425 \div 475$ & 1200 & 1400 & 10 & 40 \\
\hline
\end{tabular}

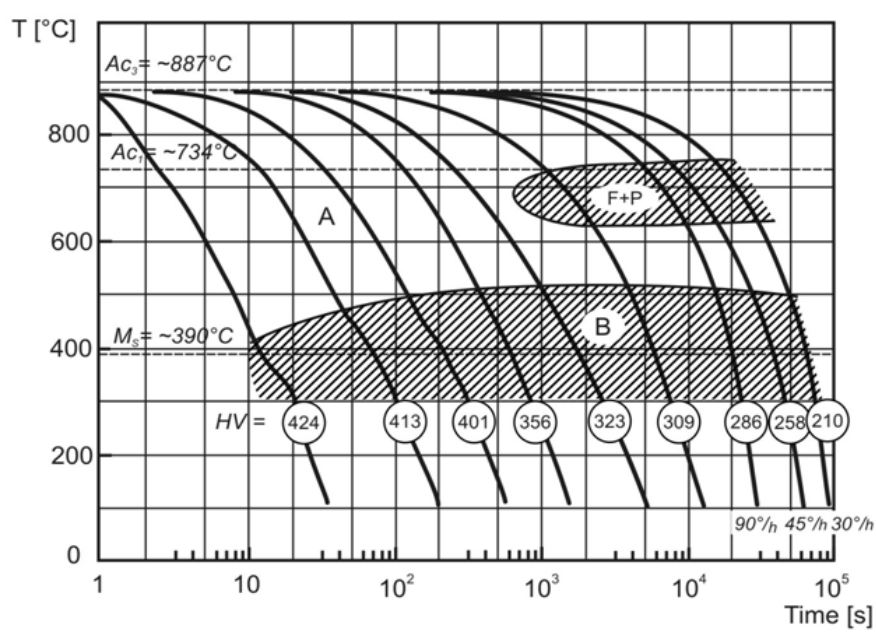

Fig. 2. CTPc diagram for steel of chemical composition $(0.16 \% \mathrm{C}, 1.45 \%$ $\mathrm{Mn}, 1.48 \% \mathrm{Cr}, 0.81 \% \mathrm{Ni}, 0.41 \% \mathrm{Mn}$ without boron)

carbide-formed elements such as chromium and molybdenum, that delay tempering processes. This is due to a lower rate of chromium and molybdenum carbides coagulation than this of cementite. In Hardox steels chromium and molybdenum are used together which enhances the effect. The molybdenum contents in range $0.25 \div 0.60 \%$ has a positive effect of secondary hardness and prevents irreversible temper brittleness at temperature of $250 \div 400^{\circ} \mathrm{C}$. Just as phosphorus, molybdenum increases the tendency to temper brittleness. As boron and molybdenum strongly increases the hardenability of hypoeutectoid steel. This effect also depends on the grain size. The finer the grain and the less content of carbon in the steel is this effect is stronger.

Operation of boron, delaying the release of ferrite and pearlite reaction is particularly clear in the presence of molybdenum. Figure 2 and 3 shows diagrams of CTPc for steel with similar to Hardox steel chemical composition without boron and with boron (Malkiewicz [7]).

Considering the roles of selected elements in chemical composition there can be determined that nickel (in amount up to $2.5 \%$ ) slightly reduces the austenitizing temperature, does not affect temper processes course and reduces the temperature of steel transition into the brittle state.

Therefore, the values of impact energy for Hardox steel range from $40 \mathrm{~J}$ for Hardox 450 to $45 \mathrm{~J}$ for Hardox 400 at $-40^{\circ} \mathrm{C}$ (for samples in accordance with the direction of plastic working). The effect of addition of boron and other elements such as boron, niobium and titanium has significant impact on reducing carbon ratio $\mathrm{CE}(\mathrm{CEV})$ with simultaneous increase in mechanical properties of Hardox steel. Significant role in Hardox steels has molybdenum and boron. Figure 4 shows the influence of boron 
Tab. 1. Hardox steel chemical compositions taking into account thicknesses of metal plates specified by the manufacturer

\begin{tabular}{|c|c|c|c|c|c|c|c|c|c|c|c|c|}
\hline \multicolumn{2}{|c|}{ Sheet thickness $(\mathrm{mm})$} & \multicolumn{9}{|c|}{ Maximum content (\%) } & \multirow{2}{*}{$\mathrm{C}_{\mathrm{EV}}$} & \multirow{2}{*}{$\mathrm{C}_{\mathrm{ET}}$} \\
\hline & & $\mathrm{C}$ & $\mathrm{Si}$ & $\mathrm{Mn}$ & $\mathrm{P}$ & $S$ & $\mathrm{Cr}$ & $\mathrm{Ni}$ & Mo & B & & \\
\hline & $3-10$ & 0.150 & 0.700 & 1.600 & 0.025 & 0.010 & 0.300 & 0.250 & 0.250 & 0.004 & 0.33 & 0.23 \\
\hline & $10-20$ & 0.150 & 0.700 & 1.600 & 0.025 & 0.010 & 0.500 & 0.250 & 0.250 & 0.004 & 0.37 & 0.27 \\
\hline & $20-32$ & 0.180 & 0.700 & 1.600 & 0.025 & 0.010 & 1.000 & 0.250 & 0.250 & 0.004 & 0.48 & 0.29 \\
\hline \multirow[t]{6}{*}{ Hardox 400} & $32-45$ & 0.220 & 0.700 & 1.600 & 0.025 & 0.010 & 1.400 & 0.500 & 0.600 & 0.004 & 0.57 & 0.31 \\
\hline & $45-51$ & 0.220 & 0.700 & 1.600 & 0.025 & 0.010 & 1.400 & 0.500 & 0.600 & 0.004 & 0.57 & 0.38 \\
\hline & $51-80$ & 0.270 & 0.700 & 1.600 & 0.025 & 0.010 & 1.400 & 1.000 & 0.600 & 0.004 & 0.73 & 0.48 \\
\hline & $80-130$ & 0.320 & 0.700 & 1.600 & 0.025 & 0.010 & 1.400 & 1.500 & 0.600 & 0.004 & 0.73 & 0.48 \\
\hline & $3-10$ & 0.190 & 0.700 & 1.600 & 0.025 & 0.010 & 0.250 & 0.250 & 0.250 & 0.004 & 0.41 & 0.30 \\
\hline & $10-20$ & 0.210 & 0.700 & 1.600 & 0.025 & 0.010 & 0.500 & 0.250 & 0.250 & 0.004 & 0.47 & 0.34 \\
\hline \multirow[t]{4}{*}{ Hardox 450} & $20-40$ & 0.230 & 0.700 & 1.600 & 0.025 & 0.010 & 1.000 & 0.250 & 0.250 & 0.004 & 0.57 & 0.37 \\
\hline & $40-50$ & 0.230 & 0.700 & 1.600 & 0.025 & 0.010 & 1.000 & 0.250 & 0.600 & 0.004 & 0.59 & 0.36 \\
\hline & $50-80$ & 0.260 & 0.700 & 1.600 & 0.025 & 0.010 & 1.400 & 1.000 & 0.600 & 0.004 & 0.72 & 0.41 \\
\hline & & & \multicolumn{8}{|c|}{$\begin{array}{l}C_{E V}=C+\frac{M n}{6}+\frac{C r+M o+V}{5}+\frac{C u+N i}{15} \quad(I I W) \\
C_{E T}=C+\frac{M n+M o}{10}+\frac{C r+C u}{20}+\frac{N i}{40} \quad(S E W 088)\end{array}$} & & \\
\hline
\end{tabular}

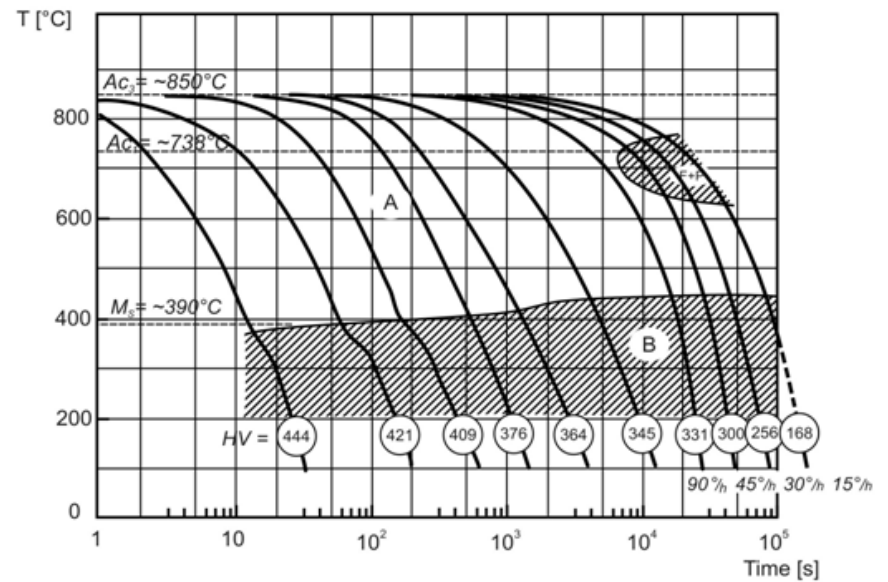

Fig. 3. CTPc diagram for steel of chemical composition $(0.16 \% \mathrm{C}, 1.45 \%$ $\mathrm{Mn}, 1.48 \% \mathrm{Cr}, 0.81 \% \mathrm{Ni}, 0.41 \% \mathrm{Mo}, 0.0017 \% \mathrm{~B})$

on the course of $\mathrm{CTP}_{\mathrm{i}}$ line for steel with chemical composition similar to Hardox 400.

Authors of works (Pękalski et al. [10], Tillová et al. [11]) indicate that boron bonds to austenite boron carbides $\mathrm{M}_{23}(\mathrm{C}, \mathrm{B})_{6}$. Other elements $(\mathrm{Nb}$ and $\mathrm{Ti})$ bond to stable carbides, nitrides and carbonitrides limiting grain growth of austenite during steel hardening process. Tempered martensite structure has better mechanical properties as compared with the structure of bainite tempered at the same temperature. Also, the ratio of yield stress to ultimate strength in function of ductile-brittle transition temperature is preferred in case of structures with after-martensitic orientation (Tillová et al. [12]).

Observations of the samples of not etched Hardox 400 and 450 steels (manufactured in accordance with ISO 4967-1979) showed the presence of a small amount of non-metallic inclusions uniformly distributed mainly in the form of brittle silicates, oxides, nitrides of titanium and sulphides (Fig. 5).

Metallographic analysis was carried out by means of an optical microscope NEOPHOT 32. As a result of carried out

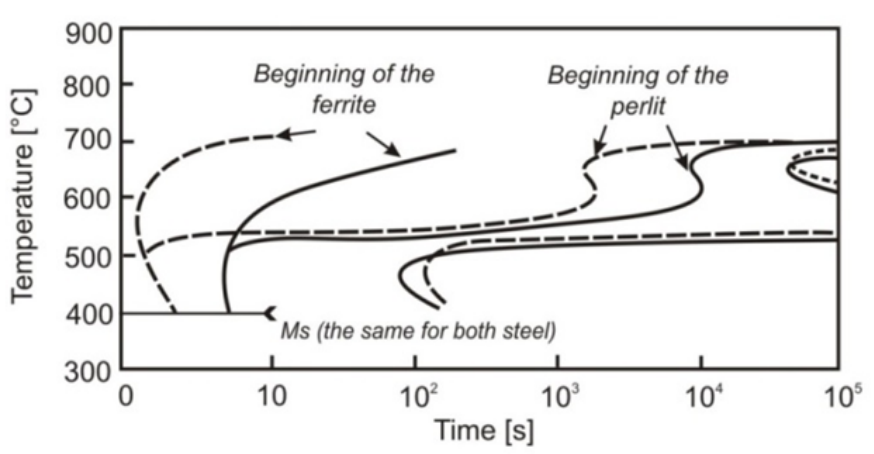

Fig. 4. The effect of addition of boron on the location of the CTPi graph lines in steel with chemical composition: $0.16 \% \mathrm{C}, 0.60 \% \mathrm{Mn}, 1.92 \% \mathrm{Ni}, 0.27 \% \mathrm{Mo}$, close to Hardox 400 (Blicharski [1])

analysis of microstructure it was found that Hardox 400 steel (Fig. 6) as well as Hardox 450 (Fig. 7) has a structure of tempered martensite. Steels that have been tested are characterized by coarsely acicular martensitic structure.

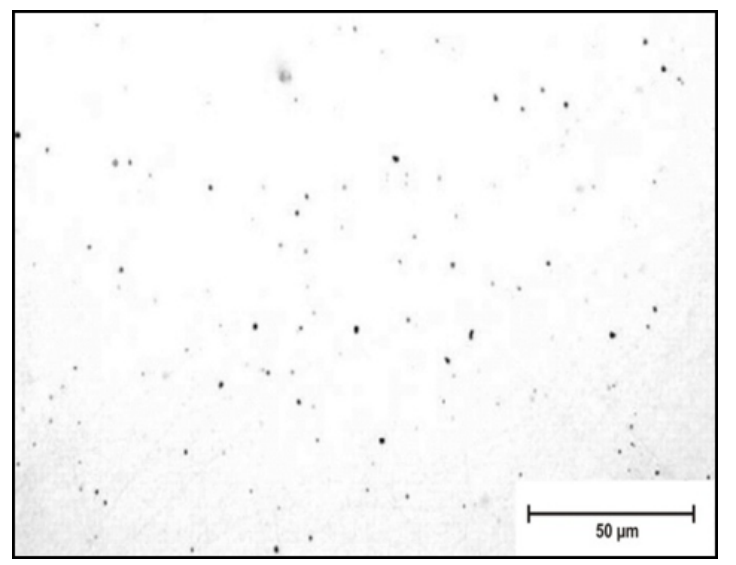

Fig. 5. Character of surface, Hardox 400 steel

Nonmetallic inclusions mostly in the form of sulfides, oxides, silicates and nitrides evenly spaced cross-section specimen. 


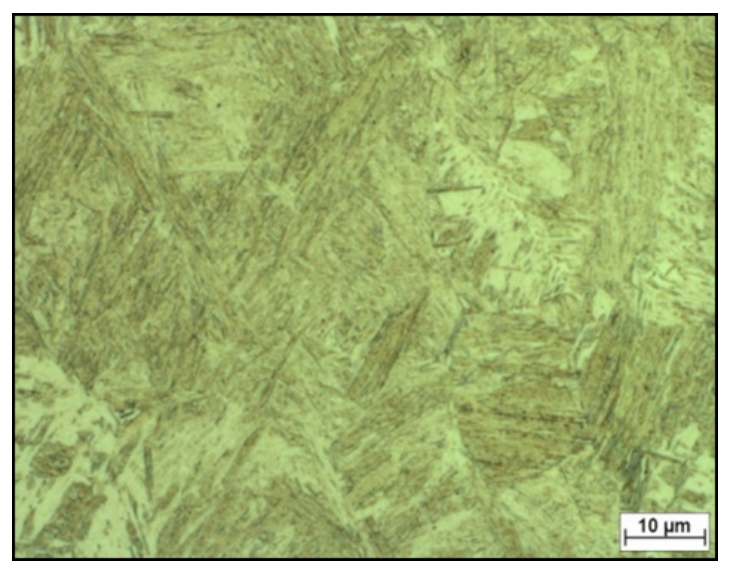

Fig. 6. Microstructure of Hardox 400 steel, etching Mi1Fe

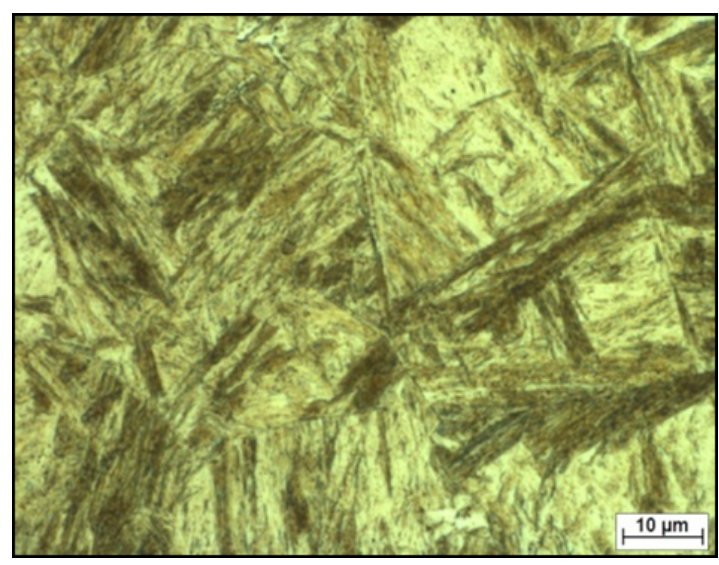

Fig. 7. Microstructure of Hardox 450 steel, etching Mi1Fe

\section{Fatigue Properties}

Fatigue tests were given to samples of S355J2 structural steel, Hardox 400 and Hardox 450. Samples of the shape shown in Figure 8 were used. The fatigue test was performed by means of the Rotoflex device in a research laboratory of The Department of Material Engineering at The University in Žilinia. This device allows to load sample in such a way as the force of bending moment has a constant value on the entire length of the working sample. In the load cycle asymmetry coefficient was $\mathrm{R}=-1$, with load frequency of $40 \mathrm{~Hz}$ and temperature $20^{\circ} \mathrm{C} \pm 3{ }^{\circ} \mathrm{C}$ (Nový et al. [8], Palček et al. [9]). The operative portion of the test sample was cooled by fans. Out of the results of the experiment, there were constructed amplitude curves of the applied load on the number of cycles up to a breaking moment of the sample $\sigma_{\mathrm{a}}=$ $\mathrm{f}\left(\mathrm{N}_{\mathrm{f}}\right)$ (Fig. 9) for each steel.

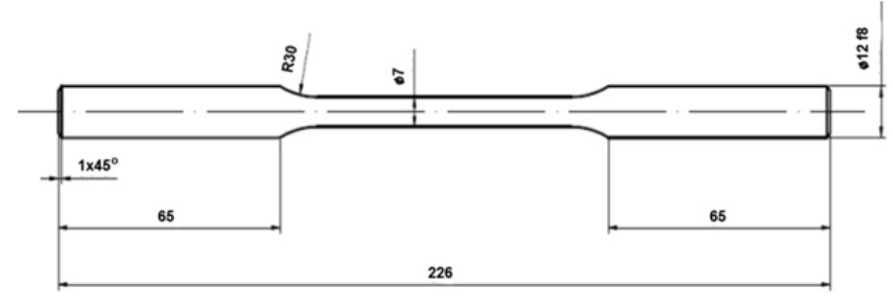

Fig. 8. Shape and dimensions of specimens used on Rotoflex equipment

Carried out fatigue study showed that in the case of Hardox 400 , fatigue limit was $490 \mathrm{MPa}$, the amplitude difference was

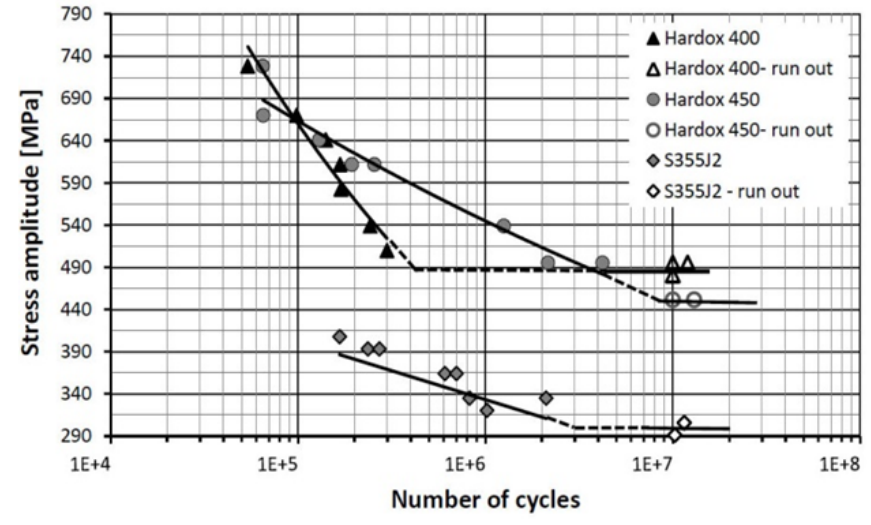

Fig. 9. Diagram of dependency between the load amplitude and number of cycles of the tested steels

$\Delta \sigma_{\mathrm{a}}=235 \mathrm{MPa}$. In case of Hardox 450 steel fatigue limit was $460 \mathrm{MPa}$, with $\mathrm{N}=10^{7}$ value of number of cycles. The results are close to each other, the difference is due to the higher strength and hardness properties of Hardox 450 steel.

Comparative sample made of S355J2 steel showed clear fatigue limit at level of $\sigma_{\mathrm{c}}=290 \mathrm{MPa}$ in terms of stress cycles $10^{6}<\mathrm{N}<10^{7}$. Carried out fatigue study showed that in the case of Hardox 400, fatigue limit was $490 \mathrm{MPa}$, the amplitude difference was $\Delta \sigma_{\mathrm{a}}=235 \mathrm{MPa}$. In case of Hardox 450 steel fatigue limit was $460 \mathrm{MPa}$, with $\mathrm{N}=10^{7}$ value of number of cycles. The results are close to each other, the difference is due to the higher strength and hardness properties of Hardox 450 steel.

Comparative sample made of S355J2 steel showed clear fatigue limit at level of $\sigma_{\mathrm{c}}=290 \mathrm{MPa}$ in terms of stress cycles $10^{6}<\mathrm{N}<10^{7}$.

\section{Conclusion}

Carried out research and experience of WIELTON S.A. demonstrate the possibility of the use of fine-grained Hardox 400 and 450 steels in building of semi-trailers. The use of wearresistant materials, extends the life and also reduces the weight of a trailer thanks to thinner sheets used for construction of trailers. One of the key parameters is to ensure uniformity of properties throughout the cross-section of the sheet. Alloy elements such as boron and molybdenum improve the hardening qualities of Hardox steel. The study also showed that the SSAB company, which is a manufacturer of Hardox steels, provides Hardox 400 type with the upper range of hardness $420 \div 430 \mathrm{HB}$. While Hardox 450 , in the lower range of $425 \div 440 \mathrm{HB}$ of hardness, therefore, in most cases, designers use Hardox 400 for economic reasons.

Hardox 400 and 450 steels show better fatigue proprieties in comparison with S355J2 steel.

In order to obtain complete fatigue characteristics of Hardox steel, more fatigue research is needed, also in ultra-high cycle range beyond the $10^{7}$ conventional limit of cycles. 


\section{References}

1 Blicharski M, Inżynieria materiałowa. Stal, WNT; Warszawa, 2013.

2 Bokůvka O, Nicoletto G, Kunz L, Low and High-frequency Fatigue Testing, EDIS University of Žilina; Žilina, Slovak Republic, 2002.

3 Borkowski S, Ulewicz R, Selejdak J., Materiałoznawstwo dla ekonomistów, WNT; Warszawa, 2005.

4 Dima IC, Grzybowski A, Grabara J, Statistical Modeling of the Mechanical Properties of the Heavy Steel Plates - Dealing with the Ill Conditioned Data, Metalurgia International, 18(1), (2013), 11-14.

5 Dudziński W., Konat Ł., Pękalska L., Pękalski G., Struktury i wtaściwości stali Hardox 400 i Hardox 500, Inżynieria Materiałowa, 27(3), (2006), 139-142.

6 Krynke M, Selejdak J, Borkowski S, The Quality of Materials Applied for Slewing Bearing Raceway, Materials Engineering, 19(4), (2012), 157-163.

7 Malkiewicz T, Metaloznawstwo stopów żelaza, PWN; Warszawa-Kraków, 1976.

8 Nový F, Janeček M, Škorik V, Muller J, Wagner L, Very high cycle fatigue behaviour of as-extruded AZ31, AZ80, and ZK60 magnesium alloys, International Journal of Materials Research, 100(3), (2009), 288-291.

9 Palček P, Námešný A, Chalupová M, Hadzima B, Failure mechanisms in magnesium alloys matrix composites, 22nd Danubia-Adria Symposium on Experimental Methods in Solid Mechanics DAS 2005, In: 22nd DanubiaAdria Symposium on Experimental Methods in Solid Mechanics DAS 2005; Parma, Italy, 2005, pp. 145-146.

10 Pękalski G, Haimann K, Konat $七$, Badania materiałowe stali Hardox 400 $i$ stali Hardox 500, report, Vol. 1, Raport Instytutu Materiałoznawstwa i Mechaniki Technicznej serii SPR, 2005.

11 Tillová E, Chalupová M, Hurtalová L, Bonek M, Dobrzański LA, Structural analysis of heat treated automotive cast alloy, Journal of Achievements in Materials and Manufacturing Engineering/JAMME, 47(1), (2012), 19-25.

12 Tillová E, Chalupová M, Solution treatment effect on microstructure and mechanical properties of automotive cast alloy, Materials Engineering/ Materiálové inžinierstvo, 19(2), (2012), 39-46.

13 Ulewicz R, Mazur M, Nový F, Szataniak P, Fatigue Properties of Selected Grades of Steel Used for Main Components of Semitrailers and Agricultural Machines, Advanced Manufacturing and Repair Technologies in Vehicle Industry. 29th International Colloquium. 21-23 May, 2012, Zilina - Terchova, Slovakia, 21-23 May, 2012, In: Advanced Manufacturing and Repair Technologies in Vehicle Industry; Zilina - Terchova, Slovakia, 21-23 May, 2012, pp. 64-70. 